Wesleyan University

From the SelectedWorks of BASAK KUS

2015

Weak States, Unruly Capitalists, and the Rise of Étatism in Late Developers: The Case of Turkey

BASAK KUS, Wesleyan University 
This article was downloaded by: [Wesleyan University]

On: 26 April 2015, At: 18:01

Publisher: Routledge

Informa Ltd Registered in England and Wales Registered Number: 1072954 Registered

office: Mortimer House, 37-41 Mortimer Street, London W1T 3J H, UK

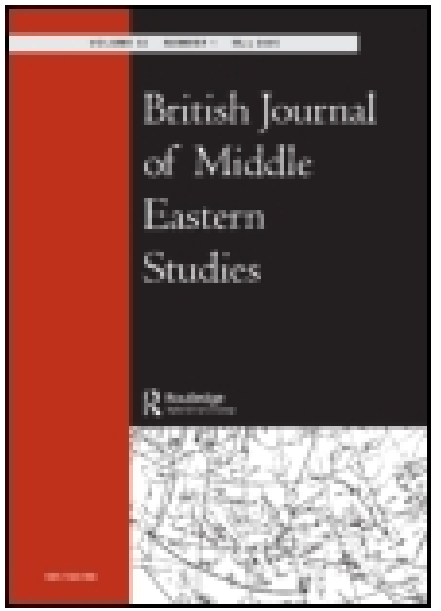

\section{British J ournal of Middle Eastern Studies}

Publication details, including instructions for authors and subscription information:

http:// www. tandfonline.com/loi/ cbjm20

\section{Weak States, Unruly Capitalists, and the Rise of Étatism in Late Developers: The Case of Turkey}

Basak Kus

Published online: 28 Nov 2014.

\section{CrossMark}

Click for updates

To cite this article: Basak Kus (2015) Weak States, Unruly Capitalists, and the Rise of Étatism in Late Developers: The Case of Turkey, British J ournal of Middle Eastern Studies, 42:3, 358-374, DOI: 10.1080/ 13530194.2014.963511

To link to this article: http:// dx.doi.org/ 10.1080/13530194.2014.963511

\section{PLEASE SCROLL DOWN FOR ARTICLE}

Taylor \& Francis makes every effort to ensure the accuracy of all the information (the "Content") contained in the publications on our platform. However, Taylor \& Francis, our agents, and our licensors make no representations or warranties whatsoever as to the accuracy, completeness, or suitability for any purpose of the Content. Any opinions and views expressed in this publication are the opinions and views of the authors, and are not the views of or endorsed by Taylor \& Francis. The accuracy of the Content should not be relied upon and should be independently verified with primary sources of information. Taylor and Francis shall not be liable for any losses, actions, claims, proceedings, demands, costs, expenses, damages, and other liabilities whatsoever or howsoever caused arising directly or indirectly in connection with, in relation to or arising out of the use of the Content.

This article may be used for research, teaching, and private study purposes. Any substantial or systematic reproduction, redistribution, reselling, loan, sub-licensing, systematic supply, or distribution in any form to anyone is expressly forbidden. Terms \& 

and-conditions 


\title{
Weak States, Unruly Capitalists, and the Rise of Etatism in Late Developers: The Case of Turkey
}

\author{
BASAK KUS*
}

\begin{abstract}
Understanding why some nations turned to étatism in the early stages of economy building remains central to political economy. A general consensus, although it comes in different versions, holds that étatism became the developmental policy in nations where indigenous entrepreneurial classes were weak and small. Traditional accounts of Turkish turn to étatism in the 1930s generally draw on this premise. This article challenges these perspectives that associate étatism with a strong state and a weak entrepreneurial class. I argue that the turn to étatism in Turkey did not simply result from the developmental shortcomings of the newly emerging private sector. The state's own shortcomings at governing the newly emerging class of self-interest seeking entrepreneurs, and instituting order in the markets was a major factor.
\end{abstract}

\section{Introduction}

The turn to étatism in late developers is often described as the state taking matters of economic growth into its own hands in cases where weak domestic entrepreneurial classes lacked the requisite capital and skills to generate rapid development. Traditional accounts of Turkish turn to étatism in the 1930s generally draw on this premise. It is argued that the weakness of the domestic entrepreneurial classes compelled the state to act as the principal economic agent in the economy. This article challenges this perspective which associates Turkish étatism with a strong state and a weak entrepreneurial class. I argue that the turn to étatism in Turkey did not simply result from the developmental shortcomings of the newly emerging private sector. The state's own shortcomings at governing the newly emerging class of self-interest seeking entrepreneurs-what Streeck calls 'the unruly capitalists' ${ }^{1}$ — was a major factor. Failing to subject the newly emerging class of domestic capitalists to a formal regulatory framework, state elites began to view them as a serious threat not only to their political authority but also to public morality, and swiftly moved to assert its overarching control over the economy. The nature of the state's encounter with the unruly capitalists at the early stages of state and economy building set the course of development policy

\footnotetext{
*Basak Kus, Department of Sociology, Wesleyan University, Middletown, CT, USA. Email: bkus@wesleyan.edu ${ }^{1}$ W. Streeck, Reforming Capitalism: Institutional Change in the German Political Economy (Oxford: Oxford University Press, 2009).
} 
for the coming three decades and left its mark on state-economy relations in the long term. Even after the 1980s-after Turkey took a decisive turn to become a market economy-successive governments took it upon themselves to politically punish the members of the business class that they saw as a threat to their authority.

In what follows I first provide a brief literature review on the rise of étatism. Then, I move on to discussing the historical conditions under which étatism became the model of economic development in Turkey from the early 1930s through the late 1940s. I conclude with a succinct discussion that puts the Turkish case in a comparative perspective.

\section{Background to the Study}

The emergence of state-led development efforts in late developers often points to the infancy and small size of the local private sector. According to Gerschenkron historically, where private economic actors lacked the capital and skills to generate growth, the state took over as a planner and industrial moderniser. ${ }^{2}$ Another view, while also pointing to the weakness of domestic entrepreneurial classes, emphasises ideology as playing an intervening role. ${ }^{3}$ According to this view, small and fledgling entrepreneurial classes fail to impose their marketoriented ideology and preferences on the state elite and remain unable to resist the rise of étatist ideas in the face of socio-economic challenges. ${ }^{4}$ Yet another view places the source of state dominance not on the weakness of capital per se, but on its weakness relative to the 'overdeveloped state'-a legacy of colonial experience. ${ }^{5}$ The common denominator of these views is that they fundamentally associate étatism with a strong state and a relatively weak entrepreneurial class.

This article challenges these perspectives through an examination of the turn to étatism in Turkey. I argue that the administrative weakness and regulatory failure of the state itself was a crucial factor in Turkey's turn to étatism. Making economic agents who are in the early stages of capital accumulation subject to a formal legal and extractive framework is not an easy task. As Chaudhry notes, governments in the developing world, although many of them remain directly involved in production and distribution, rarely possess the capacity to define and enforce property rights, tax, or collect information. ${ }^{6}$ These governance capacities, however, are absolutely necessary in a thriving market economy. Thus, 'understanding how these capacities evolve or fail to evolve' is crucial to understanding both initial patterns of government intervention in the economy and the fate of future reforms. ${ }^{7}$

In the formative years of the Turkish Republic, from the early 1920s through the end of 1940s, the state lacked the administrative capacity to establish an

\footnotetext{
${ }^{2}$ A. Gerschenkron, Economic Backwardness in Historical Perspective: A Book of Essays (Cambridge, MA: Belknap Press of Harvard University Press, 1962).

${ }^{3}$ E. Wilson, 'Strategies of State Control of the Economy: Nationalization and Indigenization in Africa', Comparative Politics, 22(4) (1990), pp.401-419.

${ }^{4}$ Wilson, 'Strategies of State Control of the Economy', (1990), pp. 401-419.

${ }^{5}$ H. Alavi, 'The State in Post-colonial Societies: Pakistan and Bangladesh', New Left Review, 74 (1972), pp. 59-81.

${ }^{6}$ K. Chaudhry, 'The Myths of the Market and the Common History of Late Developers', Politics and Society, 21 (4) (1993), p. 250.

7 Chaudhry, 'The Myths of the Market and the Common History of Late Developers', p. 250.
} 
enforceable legal framework. This in turn created an authority vacuum that was met with opportunistic behavior on the part of the new class of private entrepreneurs. While state elites were keen on making the country's new indigenous entrepreneurs subject to a set of formal rules without having the capacity to do so, the new class of entrepreneurs was eager to test the state's boundaries of legal and political authority in their quest to accumulate capital quickly. In this context the relationship between state elites and the new entrepreneurs became highly conflictual. Political elites who held key positions in the government abandoned market-based development strategy, and began to call for greater state intervention. To be sure, ideas in favour of greater state intervention in the economy had been a part of the political discourse since the early days of the Republic. However, in the final analysis it was the actual experience of failure to govern the burgeoning private sector, and its political ramifications for the governing party that determined the turn the government took towards étatism.

On the theoretical front, this study draws on Chaudhry's work on the administrative weaknesses of the late developers, Fligstein's work on 'markets as politics', Streeck's work on 'unruly capitalists', and Mann's work on the types of state power.

Fligstein views state building and economy building as mutually dependent processes. ${ }^{8}$ States establish rules of exchange, property rights, and governance structures to provide stable and reliable conditions, within which economic actors operate. Property rights define the relation between business elites and the state. Governance structures refer to the general rules in a society that define relations of competition, cooperation, and market-specific definitions of how firms should be organised, and rules of exchange define who can transact with whom and the conditions under which transactions are carried out. Establishing these structures and rules, Fligstein recognises, is a political and often discordant process whereby powerful economic actors try to shape the rules in line with their own interests. ${ }^{9}$

Similarly, Streeck argues that private entrepreneurs incessantly look for ways to interpret the rules in their favour 'in a culture that fundamentally approves of innovation in rule following, if not in rule violation'. ${ }^{10}$ Regulating the "unruly capitalists' - that is actually making them subject to a stable legal institutional framework, is therefore a challenging task. Private and collective interests need to be reconciled, and on the way, political fights need to be fought. It is within the moulds of the political interactions between state and economic actors that the course of development policy, whether market-oriented or state-led, comes to shape.

Chaudhry emphasises the difficulties encountered by late developers in constructing effective legal and regulatory institutions in the process of building an economy. ${ }^{11}$ According to Chaudhry, creating and regulating markets require myriad financial, legal, and civil institutions, with stable and firm long-term commitments. However, governments in the developing world rarely possess the 'qualities associated with Adam Smith's "watchman state.", 12 Although many

\footnotetext{
${ }^{8}$ N. Fligstein, The Architecture of Markets: An Economic Sociology of Twenty First Century Capitalist Societies (Princeton University Press, 2001).

${ }^{9}$ Fligstein, The Architecture of Markets.

${ }^{10}$ Streeck, Reforming Capitalism, p. 28.

${ }^{11}$ Chaudhry, 'The Myths of the Market', pp. 245-274.

12 Chaudhry, 'The Myths of the Market', p. 250.
} 
governments remain directly involved in production and distribution, 'their capacities to regulate, define, and enforce property rights, dispense law, tax, and collect information are strictly circumscribed or nonexistent'. ${ }^{13}$ From a purely administrative perspective, 'the level the involvement of the state as a producer, direct employer, and lender in countries lacking a regulatory infrastructure is simpler than, and thus preferable to, the much more elusive alternative of regulating a market economy'. ${ }^{14}$ Hence, Chaudhry argues, it is not surprising to find that major attempts to reform the private sector in developing countries end with nationalisation: "the most intrusive economic policies of late developers often grow out of these failures to create acceptably functioning markets, signaling the administrative ineffectiveness of regulatory and extractive institutions in late developers'. ${ }^{15}$ In arguing so, Chaudhry challenges the perspectives inspired by Gerschenkron which hold that étatism was a reaction on the part of the state to the private sector's inability to provide the skills and capital necessary for bulky investments. Rather, she argues that étatism was the administrative shortcut taken by state elites who failed to meet the challenges involved in running a market economy.

The Turkish case illustrates Chaudhry's point that étatist solutions do not necessarily emerge in contexts characterised by the presence of a strong state and an incompetent entrepreneurial class. Quite the contrary, in Turkey the state's lack of competence in governing the growing entrepreneurial classes during the early stages of economy building remained instrumental in the turn to étatism. Étatism provided an effective solution to the state elites' 'unruly capitalist problem'. Fulfilling the role of a producer and employer was perceived as an administratively easier and politically palatable alternative to fulfilling the role of a regulator. To understand why this has been the case-that is, why direct involvement was possible in the Turkish case but regulation was not-requires clarifying the distinction between different types of state capacity, and the challenges associated with attaining those particular capacities, particularly in the historical and institutional context of late developers.

Mann's concept of infrastructural power can be helpfully invoked here. 'Infrastructural power' refers to the capacity of the state to actually penetrate civil society, and to implement and enforce its policies throughout the realm. ${ }^{16}$ States with infrastructural power tend to have well-functioning bureaucracies. They can collect information about their citizens easily, tax their income effectively, and enforce their will within the day almost anywhere in their domains. Infrastructural power entails a more sophisticated form of state capacity than 'despotic power', for instance, whereby the elite is empowered to undertake a range of actions without routine, institutionalised negotiation with civil society groups. ${ }^{17}$ More advanced capitalist democracies embody infrastructural power whereas it was quite limited in their formative stages.

The narrative about Turkey's turn to étatism, therefore warrants revision. From the perspective of this article, the case of Turkish étatism is not one of a strong state taking economic matters in its own hands. Rather, it was an undertaking of a

\footnotetext{
13 Chaudhry, 'The Myths of the Market', p. 250.

${ }^{14}$ Chaudhry, 'The Myths of the Market', p. 250.

15 Chaudhry, 'The Myths of the Market', p. 252.

${ }^{16}$ M. Mann. 'The Autonomous Power of the State', in John Hall (ed.), States in History (Blackwell, 1987).

${ }^{17}$ M. Mann. 'The Autonomous Power of the State', p. 113.
} 
weak state, in the infrastructural sense, responding to the opportunistic and lawevading behaviour of the newly emerging business groups. Seeing such activities as a serious threat not only to public morality but also to the state's political authority, the state swiftly moved to assert its overarching control over the economy in an increasingly despotic fashion. To put it in a Weberian framework, where authority-legal, rational authority in particular-lacked, power took over. Or, to use Mann's terms, where infrastructural power fell short, despotic power was exercised.

\section{Economy Building in Turkey: From the Market to the State}

\section{Creating an entrepreneurial class}

Economic development remained at the centre of Turkey's nation-building efforts in the 1920s. After the war of independence was won in 1923, the military officers who assumed the political leadership set to work on building a national economy based on an indigenous (muslim and Turkish) capitalist class. ${ }^{18}$ The task at hand was not an easy one. An authentic national bourgeoisie did not exist at the time. Thus, the state sought to create the necessary conditions for its emergence. The relatively richer fractions of the populace - the traders in Istanbul and Izmir, the small industrialists, commercialised land owners and the petty bourgeoisie of Anatolia-were assigned great importance in this period as potential leaders of economic modernisation. During his various visits to the economically dynamic cities in Anatolia in 1923, Mustafa Kemal Ataturk-the President of the newly founded Republic - stated repeatedly that the richer segments of the populace would be supported to attain economic and social development. ${ }^{19}$

In short, the Republic's founders approach to the issue of economic development had two major elements: (1) a pro-market attitude that country development would be based on private entrepreneurship, and (2) a nationalist orientation that it would be led by muslim Turkish entrepreneurs. In order to realise these objectives the Republican leaders embarked on a three-legged policy. First, they employed a liberal regulatory policy that rendered private enterprises subject to a minimum degree of legal restrictions. The rationale for this was to free private enterprises of any constraints that might hinder their development. Second, they provided various direct and indirect incentives to local entrepreneurs. These incentives, which became officially institutionalised with the enactment of the Law on Encourgament of Industry in 1927, included tax exemptions, exemptions from customs duties in the importations of raw materials and inputs to be used in local industrial production, free-of-charge allocation of state lands for the installation of industrial plants, and credit allocations through the newly established state banks. And finally, once the term of the Lausanne Treaty expired in the late $1920 \mathrm{~s}$, the government embarked on a protective trade policy ${ }^{20}$ aimed at eliminating foreign competition for domestic producers. State elites believed that

\footnotetext{
${ }^{18}$ A. Krueger and I. Turan, 'The Politics and Economics of Turkish Policy Reform in the 1980s', in Robert H. Bates and Anne O. Krueger (ed.), Political and Economic Interactions in Economic Policy Reform: Evidence from Eight Countries (Oxford: Blackwell, 1993).

${ }^{19}$ Y. Tezel, Cumhuriyet Döneminin Iktisadi Tarihi: 1923-1950 (Istanbul: Tarih Vakfi Yurt Yayinlari, 1994).; K. Boratav, Turkiye'de Devletcilik (Ankara: Savas Yayinevi, Yazim (2nd edition), 1982).

${ }^{20}$ Because of the rules of Lausanne Treaty, a protective trade policy could not be fully exercised in the earlier years of the Republic. It was in the late 1920s that it became active.
} 
these policies would lead to the development of an authentic Turkish and muslim entrepreneurial class. The cartoon below, in Figure 1, published in 1923 in a popular magazine of the time, speaks to the changing norms of the era and portrays in a humorous way the state's efforts to create a class of enterpreneurs. The cartoon shows Karagoz ${ }^{21}$ replacing the parts of a citizen's brain that are oriented towards civil servant work with parts that are oriented to trade and commerce.

Unruly capitalists against the state: Economic crimes in the early years of state building

Turkey's regulatory framework in the 1920s was far from institutionalised. The Ottoman legal code had been invalidated, the foundations of a national capitalism were just being built, and it was not clear at all in what areas and to what degree the legal authority of the state would be applied. Indeed, the state was not at all oriented to regulate, but rather to create. In an attempt not to discourage the newly emerging entrepreneurial capacity in the nation, Republican leaders did not impose clear boundaries on economic activities but rather acted in a highly pragmatic way adjusting to the needs and conditions of the time. The only area where state regulation was actively present in this period was in the realm of trade, and that was only to protect the burgeoning domestic industry. Aside from that, there were no strict limitations to entering markets and no clearly laid out rules specifying the parameters of operation within them.

The state's three-legged approach to market building, combining a pro-market regulatory policy, protective measures and generous incentives, was instrumental in the emergence of a new generation of entrepreneurs out of former farmers, craftsmen and bureaucrats. Subject to a minimum degree of legal and bureaucratic restriction, and enjoying a great deal of insulation from the competition that might have come with an open trade policy (especially in the last years of the 1920s), there was ample opportunity for the accumulation of wealth. At the same time, however, domestic markets, which were virtually unregulated, had become quickly dominated by a set of activities whose social legitimacy was in question such as profiteering, usury, black marketing, and speculation. ${ }^{22}$ Illegitimate wealth creation was perhaps most evident in the market for manufactured goods. Locally produced items, including basic commodities, which at best could be described as substandard, were offered at prices several times higher than their worth in world markets, much to dismay of the general public. The 'new industrialist' emerged in this period as a disputed and largely resented social figure in this period, becoming the subject of many political satires, cartoons and jokes. The cartoon below, in Figure 2, shows a man having died of heart attack upon seeing the price tag on a clothing item. In Figure 3, we see another cartoon portraying 'the new rich' feasting on a lavish dinner. The table and the chair where he sits are placed on corpses of the poor who, the figure implies, died of hunger. The next one in Figure 4 juxtaposes the new rich and the civil servant. We are told that the latter has no place in the new socio-economic order. The civil servant in the background

\footnotetext{
${ }^{21}$ Karagoz and Hacivat were the main characters of the traditional Turkish shadow play that became popular during the Ottoman period after the sixteenth century.

${ }^{22}$ See Ahmed Hamdi Basar's Atatürk'le Üç Ay for a lively description of profiteering, usury, black marketing, and speculation in the economy during the 1920 s.
} 


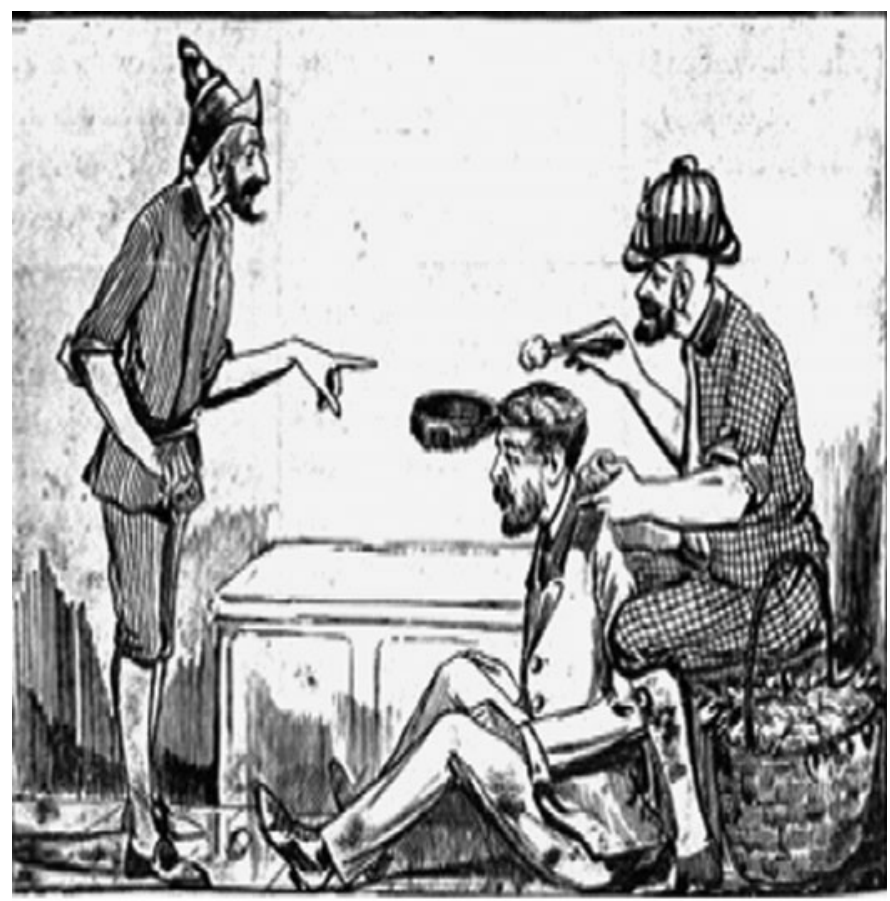

December 20, 1923 - Karagöz Dergisi

Figure 1. Creating an Enterpreneur Out of a Civil Servant. Karagoz Magazine, December 20, 1923: Hacivat: 'Dear Karagöz, what are you doing to that poor man's head?' Karagöz: 'I am just changing some parts of his brain. I am taking out the parts that are oriented towards civil servant work and replacing them with new parts that are conducive to trade and commerce.'

is ailing, starved, while the newly rich entrepreneur is proudly standing, well-fed, well-dressed.

Illegitimate wealth creation was not restricted to product markets but also extended to money markets. In the early years of the Republic, government spending including the incentives that were extended to the new entrepreneurial classes had been financed through taxes, the burden of which were born largely by the already impoverished masses - especially the peasantry. Peasants' difficulty in meeting tax payments was conducive to the emergence in the countryside of financiers and brokers lending money to local people at usurious rates. The state had virtually no rules and no controls regarding their operation.

In the context of the 1920s, such channels of illegitimate wealth creation, while they certainly met with moral discontent on the part of Republican state elites, did not become subject to immediate legal consequences. Partially due to the state's lack of regulatory power and partially out of fear that a legal intervention on the part of the state might discourage the burgeoning entrepreneurship and disrupt capital accumulation in the hands of Muslim Turks, market activities such as these were neither criminalised nor penalised. Thus, these activities continued to expand creating a deep resentment among the general public. ${ }^{23}$ In short, the state, in the first years of the Republic aimed and partially succeeded at creating the necessary

\footnotetext{
${ }^{23}$ See Ahmed Hamdi Basar's Atatürk'le Uc Ay for various anecdotes capturing this resentment.
} 


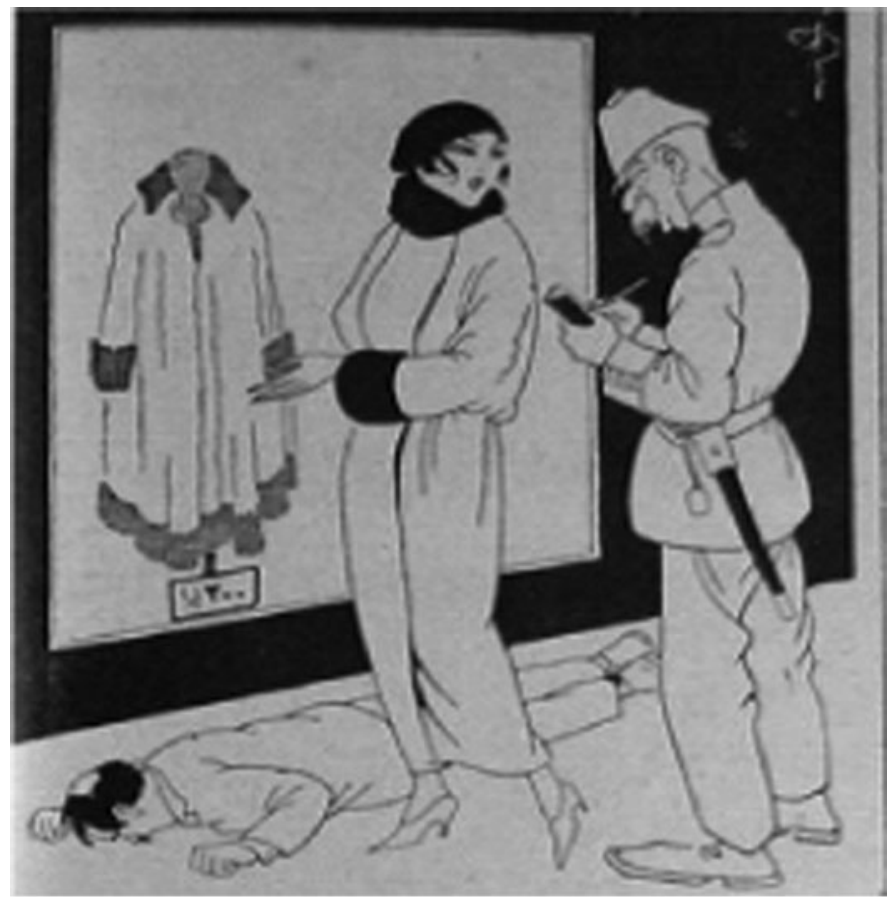

November 19, 1923 - Akbaba Dergisi

Figure 2. High Prices. Woman: 'He fainted when I asked him to buy me this coat.' Police officer: 'Understood. He had a heart attack'



February 21, 1924 - Akbaba Dergisi

Figure 3. The New Rich 


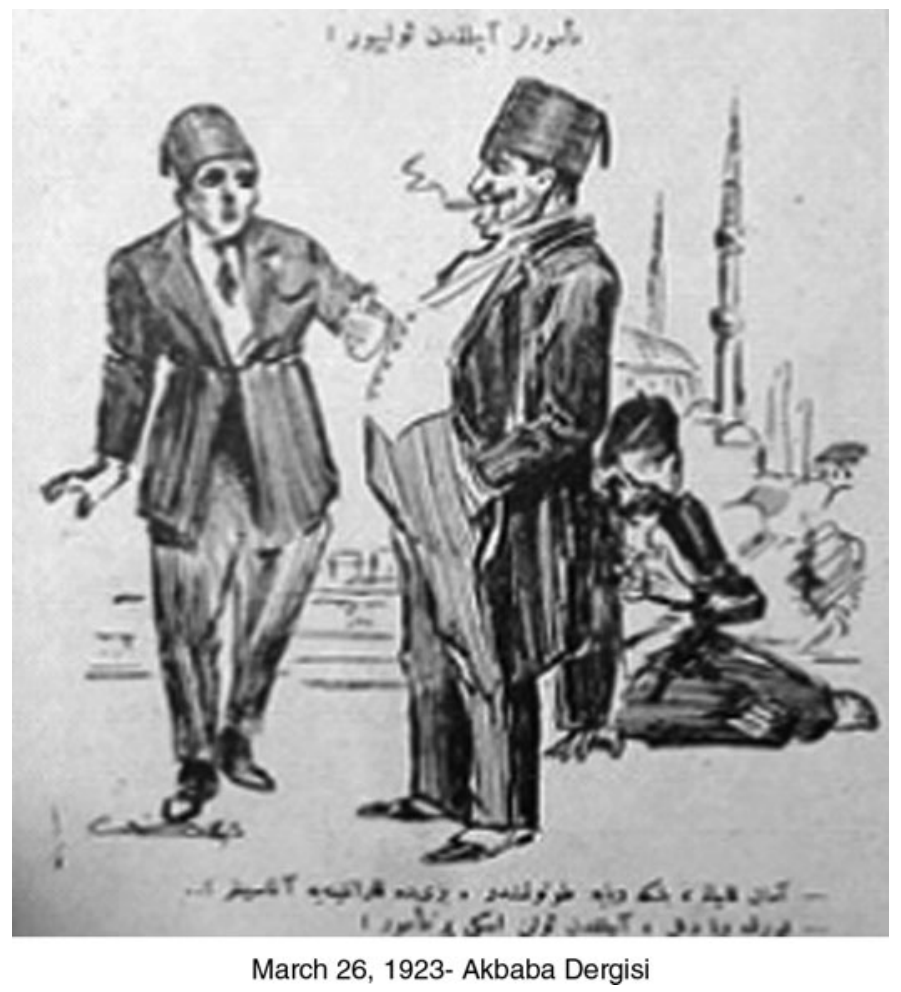

Figure 4. The New Rich Versus the Civil Servant

conditions for the development of a national bourgeoisie, but failed at undertaking the sufficient steps to make these economic activities subject to a legal framework.

The written records of the meetings of the Turkish Parliament (TBMM) from the end of the 1920s demonstrate that the Parliament was home to heated discussions on how to institute order in the markets. These records indicate the almost naive astonishment and resentment of Republican era state elites regarding market actors' interest-seeking behaviour. There was great concern and criticism in the political body with the reality that private enterprises, that the state itself had made every effort to help develop, could actually hold their self-interests above and beyond the nation's and the society's collective interests - the 'greater good'. The reference point for these criticisms seems to be hardly legal. In this period characterised by near non-existence of a regulatory framework, these activities were often criticised from the point of view of social order and morality, often with appeals to social solidarity. From the perspective of the state officials, these activities, while they had not been explicitly deemed illegal, were unpatriotic. They were not the kinds of market activities that 'good Republicans' were supposed to undertake. It was not until the 1930s, with transition to étatist policies, that a legally defined response to illegitimate market activities would emerge.

\section{The state as a disciplinary agent in markets (1930-1949): The turn to étatism}

The 1930s in Turkey stated with intense questioning on the part of state officials regarding the viability and desirability of free markets. Market-based development 
policy had generated considerable growth, although it had not quite delivered the developmental leap ${ }^{24}$ that was expected from it. It had created a wealthy and virtually 'ungovernable' class of entrepreneurs that tampered with social norms and the state's objectives. Existing inequalities had further deepened. The Great Depression was now at the door, which further intensified the government's concerns regarding growth and order in the economy. As Hale points out, 'the world-wide collapse of capitalism had undermined the conventional assumption that the capitalist economy was basically self-regulatory, and that periodic down swings in economic activity would soon be ironed out by free market forces'. ${ }^{25}$

In this context of the early 1930s, ideas in favour of a state-led economy - an étatist economy - began to take hold in political circles. Those in favour of étatism as a model of development argued that this would not only ensure boosting industrial growth but also help restore order in the markets.

Among the most contested questions in political and intellectual circles in the early 1930s was where the boundaries of state intervention in the economy would begin and end. Would the state replace private initiative or remain complementary to it? Answers to these questions were far from obvious from the very start. Étatism had its radical critics, as well as its staunch supporters. Even among those who supported étatism, as Hale notes, there were fractions that differed in ideas about its ultimate purpose and form. ${ }^{26}$ In essence, étatism's supporters in the early 1930s formed two broad schools of thought. On the one hand were the 'radicalreform nationalists' who saw étatism as a permanent alternative to capitalism. ${ }^{27}$ Influenced by the expansion of illicit activities at the end of the 1920s, the advocates of radical étatism had a tendency to see the businessman as a "potential outlaw, if not traitor'. ${ }^{28}$ Hence, they demanded a central role for public enterprises and strict limitations on the operations of private initiative. On the other hand were moderates who saw private initiative as essential and beneficial to the country's future. They regarded étatism as a 'temporary expedient' and asserted that its goal was to 'act as a nursemaid', to compliment rather than to replace indigenous capitalist development. $^{29}$

In its early days in the 1930s, Turkish étatism displayed a pragmatic character more in line with its moderate interpretations. The first practical manifestation of this was the first five-year development plan which was implemented during 1934-1938 and provided for state-controlled and financed plants for the manufacture of textiles, paper, ceramics, glass, cement, chemicals, iron and steel. ${ }^{30}$ The government also put in effect a series of new laws to regulate banking, trade and taxation (see Table 1). Wages and prices of most goods began to be controlled in supported industries. Interest rates in financial transactions and

\footnotetext{
${ }^{24}$ Especially missing were large enterprises that the Republican officers hoped would develop thanks to the favourable regulatory climate of the time. By 1927,79 per cent of enterprises in the country still had less than four employees (Tokgoz 1999).

${ }^{25}$ W. Hale, 'Ideology and Economic Development in Turkey: 1930-1945', British Society for Middle Eastern Studies Bulletin, 7(2) (1980), p. 104.

${ }^{26}$ Hale, 'Ideology and Economic Development in Turkey'.

27 Ismet Inonu who would become the President of the Republic immediately after Ataturk's death, and Recep Peker who would in the coming years become the Prime Minister were in this group.

28 A. Buğra, State and Business in Modern Turkey: A Comparative Study (Albany, NY: SUNY Press, 1994), p. 110.

${ }_{29}$ Celal Bayar who would become the Minister of Economy between 1932 and 1938 endorsed the moderate view. Hale, 'Ideology and Economic Development in Turkey', p. 107.

${ }^{30}$ W. Hale, 'Ideology and Economic Development in Turkey'.
} 
Table 1. Key Regulations (1930s)

\section{0:}

Law regarding the value of Turkish Currency

Law regarding the Foundation of the Central Bank

Law on the prevention of speculation and hoarding

1931:

Law regarding import Restrictions

Tax law

1933:

Law regarding bank deposits

Law regarding Income tax

1934:

Law regarding bids

1936:

Law regarding operation of banks

Labor law

Additiona 1 regulations regarding the prevention of speculation and hoarding

banking activities were fixed. In 1930, the Law on the Prevention of Speculation and Hoarding was passed, and in 1932, the Law for the Prevention and Punishment of Smuggling.

State officials became more vocal during this period about the legal boundaries within which they expected economic actors to operate. The government was now explicitly declaring that its objective was not to simply create markets but also to regulate them, and make sure that they operate in line with the state's objectives and legal boundaries.

The term 'normal capitalist,' which the state officials often invoked in this period, was symbolic of the state's efforts to emphasise those boundaries. Speaking at the ruling Republican People's Party Congress in 1931, Recep Peker ${ }^{31}$ noted that the government had no qualms with the 'normal' capitalists and then moved on to describe the regulatory perspective and formalisation effort embodied in étatism in the following way:

Our party is a friend of free markets and entrepreneurs that operate within normal bounds.

We are foes of abusive, illegitimate, opportunistic capital. In the years following the war many entrepreneurs acted upon their ambition to become millionaires in a short time. Many of these illegitimate enterprises have gone astray. But still, to this day, the honesty of working with the legitimate profit of normal commerce has not been established. The entrepreneurs of this era have not acted in conformity with even the most basic conventions of economic life. They covered up their accounts and fooled everyone. They have failed at last but as they went down, they dragged others with them. What this has led to is lack of trust in our markets. Our party sees it essential to fight with this mentality ${ }^{32}$

The deepening of étatism: Unruly capitalists as the enemy of the state and public

Despite their significant discontent with the flurry of illicit economic activity that had emerged in the last years of the 1920s, Republican officers, as Peker's speech shows, had not yet officially embraced an anti-market ideology. Their

\footnotetext{
${ }^{31}$ Recep Peker played a key role in the incorporation of étatism in the Party program.

${ }^{32}$ Recep Peker quoted in Boratav, Turkiye'de Devletcilik, p.120, translation and emphasis mine.
} 
condemnation was directed at a few bad apples rather than the whole of private initiative.

Turkish étatism took an authoritarian turn in the second half of the 1930s. Two developments were instrumental to this. First, despite the less than favourable conditions imposed by international and domestic developments the Turkish economy had witnessed the emergence of a new and dynamic entrepreneurial class between the two world wars. A study conducted in 1960, which collected data on 126 firms, found that 16 per cent of those firms were founded between 1923 and $1939 .{ }^{33}$ Another study showed that as of 1965 nearly half of the biggest firms operating in country were founded before 1940. Furthermore, some of Turkey's biggest family holding companies started operation between 1920 and 1950, as seen in Table $2{ }^{34}$ When it is taken into consideration that there were only 264 factories in Turkey with ten or more workers as of 1915, it is better understood that a there was a steadily growing business community in Turkey.

As their numbers increased and wealth accumulated, business people became more vocal in raising their opinions about the steering of the economy, and began to make demands from the government. Forging personal relations with political elites became a part of doing business and attaining favours, particularly for the new industrialists. The appointment of Celal Bayar known for his relatively liberal views in 1932 to the position of the Minister of Economy replacing the staunchly etatist Mustafa Sener was interpreted in political and journalistic circles as a sign of increasing influence of the business community over the government. $^{35}$

The fact that a social group had accumulated enough wealth and power to influence the policies of the state was disconcerting to certain key members of the RPP. As Kruger and Turan note, 'any social group enjoying an autonomous basis of power would meet with a suspicion and resentment on the part of Republican era officials' ${ }^{36}$ The examples of this had already been seen with the closing of Terakki Perver Cumhuriyet Firkasi (Progressive Republican Party), which was banned in 1925, and Serbest Cumhuriyet Firkasi (Liberal Republican Party) in 1930, which was banned in 1932. Both parties had challenged RPP's program and supported a multi-party framework.

Second, as noted before, starting from the early 1930s the government began to display a systematic attempt to institute order to markets. This development reflected state authorities' confusion in the face of their inability to control market activities. Particularly bothersome to state officials was the prevalence of activities such as smuggling, speculation, usury and hoarding. Despite laws that were enacted precisely to prevent these types of conducts early on in the 1930s, the state had not been able to rid the markets of them. Instead, these regulations became instrumental in fostering illicit activities. This in turn strengthened the position of those figures in RPP who subscribed to a more radical version of étatism, and eventually pushed state policy into this more authoritarian brand of étatism. From the perspective of those RPP officials, the prevalence of such activities had

\footnotetext{
${ }^{33}$ Buğra, State and Business in Modern Turkey, p. 83

34 Buğra, State and Business in Modern Turkey, p. 89.

${ }^{35}$ Buğra, State and Business in Modern Turkey, p. 149.

${ }^{36}$ Krueger and I. Turan, 'The Politics and Economics of Turkish Policy Reform in the 1980s', in Robert H. Bates, and Anne O. Krueger (ed.), Political and Economic Interactions in Economic Policy Reform: Evidence from Eight Countries (Oxford: Blackwell, 1993).
} 
Table 2. The Foundation Years of Turkey's Major Holding Companies

\begin{tabular}{ll}
\hline 1920s & Koc \\
& Cukurova \\
& Sonmez \\
& Ozakat \\
& Santral Mensucat \\
1930s & Sabanci \\
& Sapmaz \\
& Vakko \\
1940s & Yasar \\
& Ezcacibasi \\
& Ercan \\
& Transturk \\
\hline
\end{tabular}

undermined the relationship between the state and market, proved the undependability of private initiative, and at the same time had made the ruling party RPP look incompetent in the eyes of the general public.

The deepening of étatism starting in the late 1930s thus implied a further attempt on the part of the state consolidated its authority over markets that were becoming more difficult to control. In a speech he gave in 1935 Recep Peker justified the deepening of the étatist paradigm with the following words:

Turkey has built big customs walls, and has provided all sorts of incentives to support domestic industry. But the state cannot tolerate domestic industry to operate without controls and to take advantage of our nation. Supporting the industry that does not work normally is not even thinkable. ${ }^{37}$

As such, the regulatory relationship between the state and economy was caught in a circular dynamic. The heavy-handed approach of political elites towards the business community was instrumental in fostering illicit activities, while at the same time, it was reinforced by these activities. ${ }^{38}$ The more they failed at governing, the more they became resentful (Bugra 165). Turkey's experience with increasing state intervention resulting from regulatory failure remains common to the 'history of late developers' where, as Chaudhry ${ }^{39}$ points out, 'the most intrusive economic policies often emerged out of failures to create acceptably functioning markets signalling the administrative ineffectiveness of regulatory and extractive institutions'. Although it is not in the purview of this article to examine the state-economy relationship beyond the 1940s, it might be helpful to note that the same patterns continued into the 1950s. The 1950s would witness the growth of the private sector under a government that supported limited state intervention in the economy. At the same time, the challenges of governance would once again provide room for law-evading behaviour on the part of the private economic actors. It is only once a significant pool of industrialists emerged in the 1960s that we see this circular dynamic beginning to change. The industrial bourgeoisie in the 1960s, although having initially benefited from regulatory loopholes in accumulating capital earlier would now

\footnotetext{
${ }^{37}$ Quoted in Boratav, Turkiye'de Devletcilik, pp. 135-136, translation my own.

${ }^{38}$ Buğra, State and Business in Modern Turkey.

${ }^{39}$ Chaudhry, 'The Myths of the Market', p. 252.
} 
prefer long-term stability and predictability to the profitable but fluctuating circumstances of a weak state. This historical development also remains in line with Chaudhry's ${ }^{40}$ observation of the capitalists' position vis-à-vis state regulation in developing nations, that 'once domestic markets have expanded beyond the "transparent" transactions described by Braudel, producers and capitalists themselves develop an avid interest in regulation providing stability, predictability, and standardization'. ${ }^{41}$

When the 1930s ended, the state was still promoting the growth of domestic markets. Between 1933 and 1939 real GDP grew by an average of around 8 per cent per year. There was also a significant improvement in Turkey's foreign trade record. The balance of visible trade which had created a persistent deficit until 1930 became a surplus throughout the 1930s. The 1930s also saw the beginning of a structural shift in the Turkish economy as the share of industry began to increase. At the same time however, the state-market relationship was increasingly characterised by a lack of mutual trust and struggle for power. Private entrepreneurs were uncomfortable with not having a clear idea about how far the boundaries of state intervention would stretch, while the state was suspicious of private entrepreneurs for becoming an autonomous basis of power and putting their interests over the national interests. The entering of the principle of étatism in the constitution as a constituent part of the country's political regime in 1937, legally rendering 'liberalism' a crime, was a consequence of these concerns. ${ }^{42}$

In terms of the state-economy relationship, the 1940s in Turkey were 'tensionridden years'. ${ }^{43}$ The first controversy broke out in the wake of the enactment of the National Defence Law which gave the government extensive powers to interfere in economic activities to deal with the special circumstances created by World War II. ${ }^{44}$ The Turkish economy was characterised by a considerable degree of illicit activity even before the outbreak of the war. The National Defence $\mathrm{Law}^{45}$ was, literally, a defence strategy on the part of the state against activities which the government thought would multiply in the war years. It equipped the state with 'total freedom to act in matters of the economy'. 46 With this law the government became able to set production targets for private industry, deny approval to investment projects, confiscate factories and mines, control prices, nationalise trade in certain commodities, and force labour. This authoritarian strategy did not prove useful however in terms of restraining illicit activities. The dire conditions of the war years combined with the limited enforcement capabilities of the state made it impossible to implement and enforce what seemed to be quite far reaching and unrealistic regulations. The 1940s indeed saw a boom of illicit market activity. From this, the Republican leaders drew rather radical conclusions regarding the nature of markets and the role of the state in their operation. In 1940, in a statement addressing merchants, the Minister of commerce noted:

\footnotetext{
${ }^{40}$ Chaudhry, 'The Myths of the Market', p. 252.

${ }^{41}$ Chaudhry, 'The Myths of the Market', p. 252.

42 Buğra, State and Business in Modern Turkey, p.111.

${ }^{43}$ Buğra, State and Business in Modern Turkey, p. 112.

44 Buğra, State and Business in Modern Turkey.

${ }^{45}$ Fixing prices, requisitioning materials and forced labour were some of the things were some of the actions the Government took under the National Defence Law.

${ }^{46}$ C. Keyder, State and Class in Turkey: A Study in Capitalist Development (London, New York: Verso 1987), p.111.
} 
Since it is impossible to clearly predict the economic form which would emerge at the end of the war, it is not possible, for the moment, to have a clear idea about the usefulness of this group. ${ }^{47}$

This statement concerning private commercial activity was followed by another forceful statement addressed to the whole business community by the Prime Minister Refik Saydam:

We consider the merchant as a necessary element in national life. If this element conducts by itself its normal existence, it will receive the support of the state and the government... But, if the merchant does not understand this, we are determined to see him as an element which should be totally eliminated, and act accordingly. ${ }^{48}$

Clearly the Government which only a decade ago viewed illicit economic actors as a few bad apples in the bunch had now embraced a hostile approach to the markets and entrepreneurs as a whole. Refik Saydam's remarks above were indicative of the authoritarian stance his government would observe vis-à-vis the markets and so was the following speech given by President Inonu in the Turkish Parliament in 1941:

An irrational economic environment... prices well above and beyond what can be rightfully justified ... merchants taking advantage of the murky circumstances of the time who, if they could, would even commodify the air we breathe ... they are audaciously trying to threaten the life and future of this great nation... We will not allow anyone or any group to rip people off under the banner of economic liberalism. ${ }^{49}$

The government under these conditions could have punished the guilty under the existing legal provisions, as Buğra suggests. ${ }^{50}$ However, it instead chose to take coercive measures to significantly diminish the entrepreneurial activity in the nation. In 1942 the Capital Tax Law was passed to raise revenue from those who had profited from the war. The tax's burden fell disproportionately on nonMuslims. Its damage to the private sector's confidence in the state was more far reaching however. The Capital Tax Law constituted the second major strain on state-business relations after the passage of the National Defence Law. The passage of a land reform bill in 1945 that called for the distribution to peasants of not only state lands but also portions of the holdings of large landowners would be the third major strain on state-business relations. For obvious reasons, the spirit of all of these laws greatly disturbed the private commercial and industrial classes. ${ }^{51}$

However justified they were by the heavy presence of illicit activity, the arbitrary nature of these laws and the brutal way in which they were implemented undermined the citizens' confidence in the state and the ruling party. This was particularly true of the bourgeoisie who, as Ahmad argues had grown completely discontent with the unpredictable behavior of the autocratic state and no longer felt secure living under a regime over which they had no control. ${ }^{52}$

While government legislation regarding the operation of market activities expanded in this period, the administrative machinery that would guarantee its implementation did not develop. In the end, the regulatory environment of the

${ }^{47}$ Quoted in Buğra, State and Business in Modern Turkey, p. 112.

${ }^{48}$ Quoted in Buğra, State and Business in Modern Turkey, p. 113, emphasis my own.

${ }^{49}$ Quoted in Tezel, Cumhuriyet Döneminin Iktisadi Tarihi, p. 261, translation my own.

${ }_{51}^{50}$ Buğra, State and Business in Modern Turkey, p.114.

${ }_{51}^{5}$ M. Penner Angrist, Party Building in the Modern Middle East (Seattle: University of Washington Press, 2006).

${ }^{52}$ F. Ahmad, The Making of Modern Turkey (London; New York: Routledge, 1993), p. 71. 
period became characterised by discord between the state's regulatory ambitions and its inability to enforce its own regulations.

In the final analysis, étatist policies that attempted to regulate the economy and simultaneously achieve growth did not quite achieve the anticipated results. Between 1940 and 1945, GDP fell by an average of 6.9 per cent per annum. ${ }^{53}$ The state-economy relationship which was characterised by mutual lack of trust in the 1930s was further severed due to an authoritarian move by the state that had not been able to control the markets despite its every attempt. 'Unruly capitalism' as Republican leaders of the era had come to call it could not be restrained. The state's authoritarian actions serving that purpose, however, as many commentators of the period agree, had left their mark on state-market relations which would continue to be characterised by lack of trust in the decades to come.

\section{Discussion: Unruly Capitalists and the Abandoned Road to Markets}

The idea originally put forward by Gerschenkron that étatism embodies the state's response to the shortcomings of a small and incompetent entrepreneurial class is widely accepted in the development literature. ${ }^{54}$ Here, building on Chaudhry, Fligstein, and Streeck I offer an alternative view suggesting that étatism can take hold as an administrative short cut in nations where the state falls short at effectively regulating the entrepreneurial class.

In the period from the early 1920 s to the 1940 s political leaders in Turkey were faced with the double challenges of creating and regulating markets. The Turkish state was directly involved in cultivating the economy as a producer, employer and lender in this period. Nevertheless, the state remained seriously limited in its capacity to regulate, enforce, and dispense law, to tax, and to collect information. Creating and regulating markets proved to be incompatible processes in this period, developing not simultaneously, but often in reaction to, and at the expense of one another. Failing to subject the newly emerging domestic capitalists to formal regulations, state elites began to view them as a serious threat not only to their political authority but also to public morality.

The argument that is advanced in this study is not peculiar to the Turkish case. Chaudhry's work shows that states' regulatory failures in the economic domain gave birth to statist solutions in many late developers. ${ }^{55}$ She notes that even in the cases of the People's Republic of China, and the former Soviet Union, 'where there were obvious ideological reasons to eliminate markets the decision to nationalise all economic sectors ensued only after the state in both cases tried and failed to create functioning national markets'. Chaudhry argues that in the summer of 1917, Lenin still advocated taxation over confiscation, and that War Communism(1918-1921) only came to be an option after 'the state's failed attempts at regulating markets the immediate symptoms of which were inflation, profiteering, and hoarding and massive poverty'. 56

Similarly, the present discussion is not confined to the initial stages of economy building in late developers. In contemporary market economies as well, economic crises, which in many cases reveals the state's weaknesses in regulating the

\footnotetext{
53 Hale, 'Ideology and Economic Development in Turkey'.

${ }^{54}$ Gerschenkron, Economic Backwardness in Historical Perspective.

55 Chaudhry, 'The Myths of the Market'.

56 Chaudhry, 'The Myths of the Market', p. 253.
} 
economy, often lead to discussion of whether the failing sectors of the economy need to be nationalised or not.

Finally, although this article emphasises the regulatory shortcomings of the state vis-à-vis 'unruly capitalists' in the turn to étatism, this is not to say that other factors do not matter. In the period when Turkey turned to étatism, the international context was shaped by concerns over the impending Great Depression. As Hale points out, 'the world-wide collapse of capitalism had undermined the conventional assumption that the capitalist economy was basically self-regulatory, and that periodic down swings in economic activity would soon be ironed out by free market forces'. ${ }^{57}$ International context and the ideological currents of the time certainly mattered. The point here is not to dismiss these other factors that were at play but to challenge the strong state-weak entrepreneurial class dichotomy that seems to be the mainstream perspective in the development literature regarding the question of why states turn to étatism.

${ }^{57}$ Hale, 'Ideology and Economic Development in Turkey', p. 104. 